Article

\title{
Pigments on Roman Wall Painting and Stucco Fragments from the Monte d'Oro Area (Rome): A Multi-Technique Approach
}

\author{
Vittoria Guglielmi ${ }^{1}$, Valeria Comite ${ }^{1, *(\mathbb{D}}$, Martina Andreoli ${ }^{2}$, Francesco Demartin ${ }^{1}{ }^{1}$, \\ Chiara Andrea Lombardi ${ }^{1}$ (D) and Paola Fermo ${ }^{1}$ (D) \\ 1 Dipartimento di Chimica, Università degli Studi di Milano, 20133 Milano, Italy; \\ vittoria.guglielmi@unimi.it (V.G.); francesco.demartin@unimi.it (F.D.); lombardichia@gmail.com (C.A.L.); \\ paola.fermo@unimi.it (P.F.) \\ 2 Department of Humanities, University of Trento, 38122 Trento, Italy; martina.andreoli@unitn.it \\ * Correspondence: valeria.comite@unimi.it
}

Received: 17 September 2020; Accepted: 10 October 2020; Published: 13 October 2020

check for updates

\begin{abstract}
This work concerns the characterisation of a set of wall painting and stucco fragments collected during a rescue excavation carried out in 2013 by the Soprintendenza Archeologica in the Monte d'Oro area (Rome). Due to the contextless archaeological situation, analyses were performed to obtain more information about the collected materials. A multi-analytical approach has been applied including spectroscopic (FTIR, Raman and visible reflectance analyses) and elemental analysis (SEM-EDS) techniques. The chromatic palette has been in this way disclosed evidencing the use of pigments such as cinnabar, Egyptian blue, red and yellow ochre and green earth, but also the simultaneous use of them. The presence of a decoration achieved by using a gold leaf has been highlighted also, indicating the preciousness of the decorations. The convenience and advantages linked to the use of portable instrumentation have been also evidenced.
\end{abstract}

Keywords: wall paintings; stucco; FTIR; Raman; SEM-EDS; visible reflectance; spectroscopic techniques

\section{Introduction}

One of the most important issues in the field of cultural heritage is the characterisation of the materials employed for the realisation of paintings of historical and artistic value, since it can provide information on old technological knowledge, for instance, the painting techniques, the capabilities in the supply and production of pigments from raw materials and ancient community connections [1]. Moreover, the study of materials can also allow detecting possible restoration or conservation works, or in some cases, can even provide information on dating and/or authenticity of the artwork [2,3].

In this context, the application of suitable archaeometric methodologies, aimed at the comprehensive characterisations of pigments and binders used for the realisation of the wall paintings, is of major relevance; indeed, the chemical characterisation of the materials, joined with the information gathered from historical and archaeological studies, can be both the starting point to reach a complete understanding of the piece of art, and more in general, a precious tool available for the art conservators for restoration work.

In spite of the numerous studies having as a topic the characterisation of Roman pigments (about 250 papers in the last 20 years), due to the widespread presence of the Roman empire and also the fact that new sites keep coming to light, the investigation of the pigments and of the artists' palettes employed in Roman wall paintings is still an issue of great interest, as also witnessed by the papers published in particular during the last two years. 
The aim of the present study was the identification of the pigments used to decorate some destroyed Roman building walls, discovered between the Claudio Marcello and the Porta Latina streets in Rome (Monte d'Oro) within a private property. The fragments were rescued in 2013 by the Soprintendenza Archeologica di Roma together with a great number of ceramic shards dating mainly between the 1st and 2nd centuries A.D. Unfortunately, the wall painting and stucco fragments, and the pottery, cannot be related to any visible ancient building (probably destroyed in the 1950s) in the surroundings and are therefore to consider contextless. The fragments were in fact collected in a modern pipe trench nearby a private house, where the owners probably tried to hide archaeological material found somewhere in their property. Additionally, for this information gap, the analyses were important to obtain some further data to confirm or disappoint the archaeological interpretation. In the present study, the investigation was carried out on twelve samples chosen within all recorded colour and painting/stucco types (listed in Table 1), dating approximately between the 1st century B.C. and the 1st century A.D.

Table 1. List of investigated fragments and colours from Claudio Marcello Street.

\begin{tabular}{ccc}
\hline SAMPLE & Colour & Description and Provenance Area \\
\hline $\mathbf{1}$ & bright red & 607,354 (wallpainting) \\
$\mathbf{2}$ & red & 608,046 (wallpainting) \\
$\mathbf{3}$ & bright red & 608,043 (wallpainting) \\
$\mathbf{4}$ & purple red & 608,042 (wallpainting) \\
$\mathbf{5}$ & light red/orange & (wallpainting) \\
$\mathbf{6}$ & yellow & 608,054 (wallpainting) \\
$\mathbf{7}$ & green & 608,039 (wallpainting) \\
$\mathbf{8}$ & light blue & 608,040 (wallpainting) \\
$\mathbf{9}$ & light blue & Type 15 (stucco) \\
$\mathbf{1 0}$ & light blue & 607,286 (stucco) \\
$\mathbf{1 1}$ & white & 608,048 (wallpainting) \\
$\mathbf{1 2}$ & black & 608,050 (wallpainting) \\
\hline
\end{tabular}

The combined use of elemental analysis techniques together with spectroscopic ones represents the methodological approach which is commonly applied to fulfil the comprehensive characterisation of samples, such as Roman frescoes [4-14]. Scanning electron microscopy equipped with an energy dispersive X-ray detector (SEM-EDS), Raman spectroscopy and Fourier transform infrared spectroscopy (FTIR) techniques have been employed to establish the painting technique used to decorate the fragments. Among the analytical techniques implemented during this measurement campaign, it is worth noting that Raman spectroscopy has been successfully applied with both a benchtop device and a more versatile portable Raman spectrophotometer. Furthermore, the remarkable analytical results obtained by the portable instrument were really encouraging from the perspective of the in situ application (i.e., directly on the wall paintings) of this powerful and totally non-destructive technique. Among non-destructive measurements, visible reflectance analyses have also been performed.

Such a multi-technique approach allowed us to define the chromatic palette of the fragments, which included red ochre, hematite, yellow ochre, cinnabar, litharge, green earth (celadonite), Egyptian blue, chalk and carbon black.

\section{Materials and Methods}

\subsection{Materials}

The analysed samples consisted of 10 wall painting shards and 2 stucco fragments (Figure 1) which from an optical overview appear bright red, red, purple red, light red/orange, yellow, white, black, green and light blue. These samples, which were chosen among many others, carrying in some cases also fine decorations, synthesise the colour palette employed to decorate some vanished rooms belonging probably to one or more private roman buildings. The style and quality of some of the 
classified fragments suggest a rather high level of the wall decoration, as also demonstrated by the great variety of stucco mouldings discovered among them. These types of mouldings (an example is reported in Figure 2) were generally used on walls to hide decoration transitions. They were realised on the wet plaster and then finally overpainted with brilliant and contrasting colours. Two small stucco fragments (samples 9 and 10 in Figure 1) presenting light blue and yellow overpainting traces were therefore also selected to compare the pigments used for their decoration to the wall painting ones.

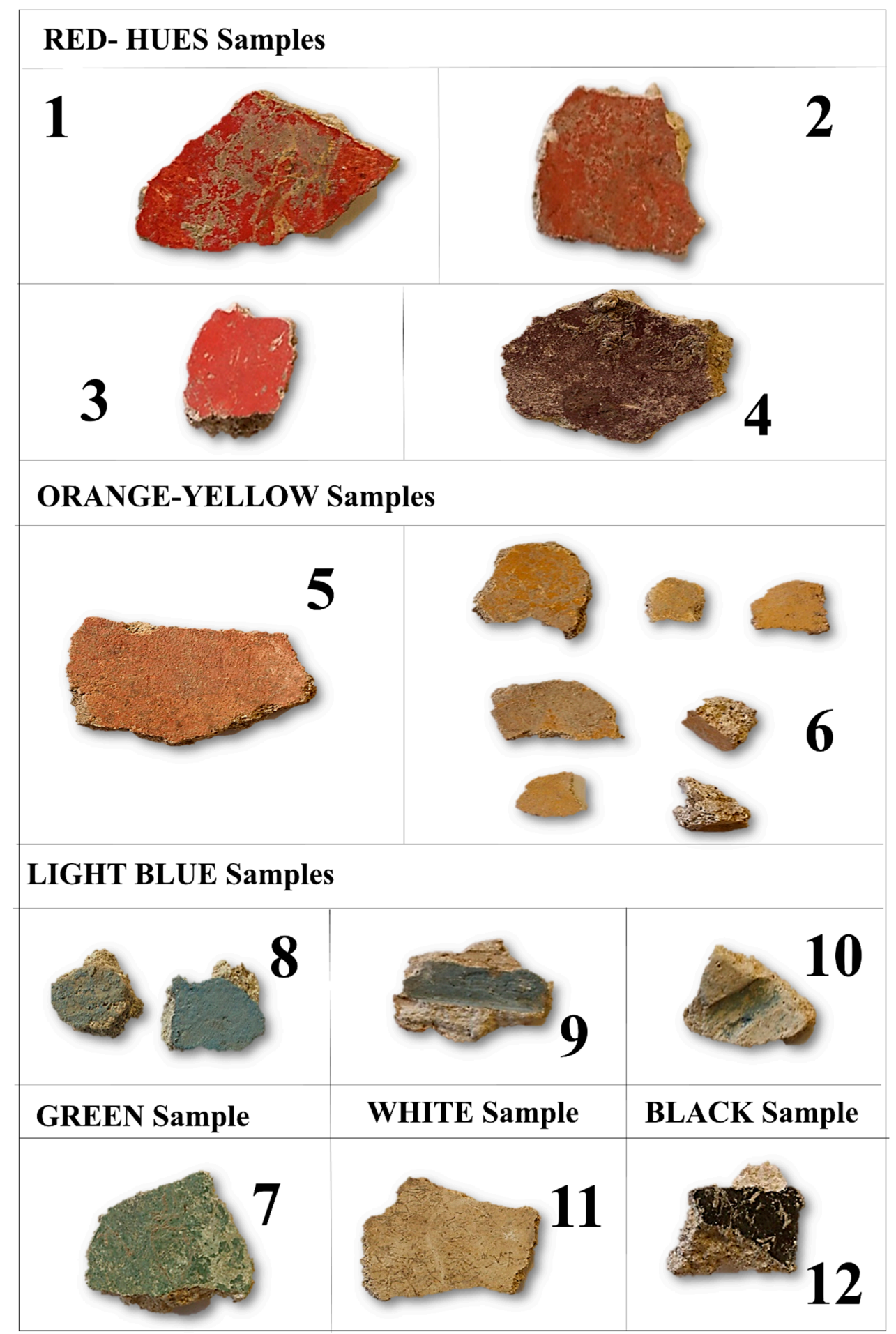

Figure 1. Photographs of the analysed painted fragments. 


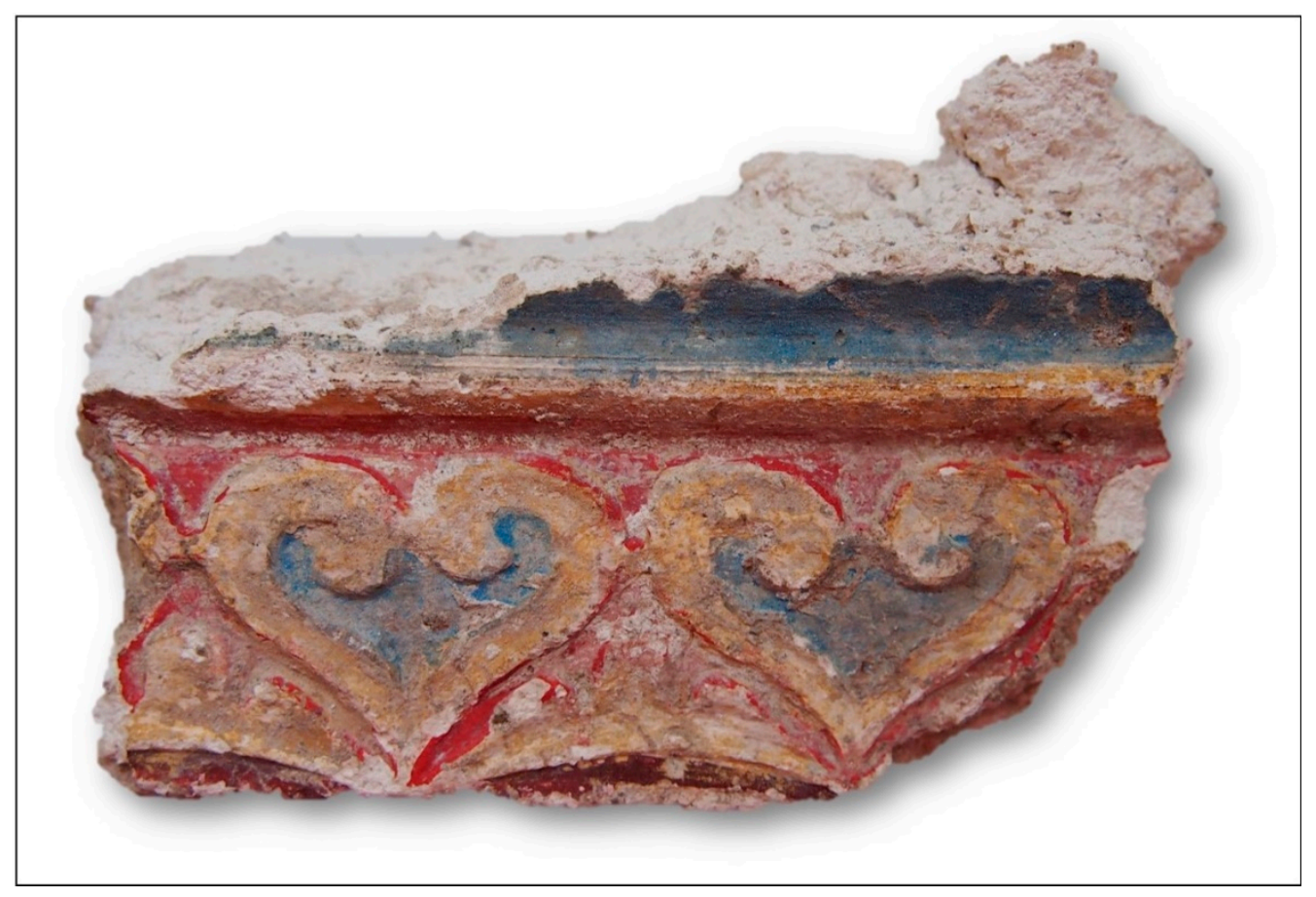

Figure 2. Example of a stucco moulding.

The sampling phase was carried out with the support of the University of Trento, which was involved by the Soprintendenza Archeologica di Roma in the archaeological study of the decorated wall and stucco fragments.

\subsection{Methods}

The shards were analysed by SEM-EDS (scanning electron microscopy coupled with energy dispersive $\mathrm{X}$-ray analysis) to obtain both qualitative and semi-quantitative information on the chemical composition, using a methodology already set up [15]. The instruments employed were a Hitachi TM-1000 equipped with a secondary electrons detector (SE) and an energy dispersive X-ray spectrometer (Oxford Instruments SwiftED); a JEOL 5500 LV equipped with secondary electron (SE) and a backscattered electrons detector (BSE); and a IXRD EDS 2000 microprobe.

In both cases the fragments were analysed without any sampling from the surface and excluding any coating application as well, the latter not being required as the samples were analysed under low vacuum conditions. The shards were attached to the sample holder with double-sided tape or removable glue pads. That is to underline that no polished cross-sections could be prepared due to the fact that it was not possible to get the permission to take sample fragments for cross-section preparation.

Basically, the Hitachi instrument was utilised to perform both the preliminary morphological observations of the samples surfaces with a secondary electron detector and the qualitative/semi-quantitative determinations as well, whereas the JEOL one, due to its higher spatial resolution, was employed to better investigate some details as in the cases of samples 1 and 6 , for which some punctual analyses have been performed.

ATR-FTIR analyses were performed by a Nicolet 380 spectrophotometer coupled with an ATR accessory Smart Orbit equipped with a diamond crystal. The spectra have been acquired from the samples in the range $450-4000 \mathrm{~cm}^{-1}$ with a $4 \mathrm{~cm}^{-1}$ resolution. Each spectrum was obtained as the result of 64 accumulations.

Raman analyses were carried out by a Thermo Fisher Raman iXR spectrophotometer equipped with a microscope and a solid-state laser emitting at $785 \mathrm{~nm}$ as an excitation source, and a BWTek i-Raman EX device provided with a fibre optic probe and an Nd-YAG laser emitting at $1064 \mathrm{~nm}$. All the 
measurements were performed directly on the fragments, without any sampling, and the spectra were obtained as averages of 20 scans in the spectral range between 200 and $2000 \mathrm{~cm}^{-1}$.

The identification of compounds was performed by comparing the FTIR and Raman spectra recorded on the samples to those available in the literature.

Finally, visible reflectance analyses have been performed by means of a Konica Minolta CM 2300d portable spectrophotometer. The instrument was calibrated using its $100 \%$ reflective white reference and a $0 \%$ reflective calibration box in the $400-700 \mathrm{~nm}$ range. All the measurements were conducted straight on the samples' surfaces.

\section{Results}

The first step of the implemented methodological approach was a widespread study of the morphologies and of the elemental chemical compositions of the surfaces of the entire sample set by means of the SEM-EDS instrument having the lower resolution (Hitachi instrument). In fact, just from the simple observation of the images achieved with that microscope, it was possible to establish the necessity of further and deeper analyses with better resolution. In Table 2, the results of the semi-quantitative chemical analysis performed by means of the aforementioned SEM-EDS are reported, normalised to $100 \%$.

Table 2. SEM-EDS semi-quantitative analyses (wt $\%$ ); for each element, the value for a sample was inferred from an average of three measurements on three different areas of the same sample.

\begin{tabular}{ccccccccccccccccc}
\hline Sample & $\mathbf{A l}$ & $\mathbf{A u}$ & $\mathbf{B a}$ & $\mathbf{C a}$ & $\mathbf{C l}$ & $\mathbf{C u}$ & $\mathbf{F e}$ & $\mathbf{H g}$ & $\mathbf{K}$ & $\mathbf{M g}$ & $\mathbf{N a}$ & $\mathbf{P}$ & $\mathbf{P b}$ & $\mathbf{S}$ & $\mathbf{S i}$ \\
\hline $\mathbf{1}$ & 2.2 & - & - & 83.1 & 0.4 & - & 2.2 & 5.1 & 1.4 & - & - & - & - & 1 & 4.5 \\
$\mathbf{1}_{\mathbf{p}}$ & - & 95.4 & - & 4.7 & - & - & - & - & - & - & - & - & - & - & - \\
$\mathbf{2}$ & 2.1 & - & - & 72.1 & - & - & 13.7 & - & 0.7 & - & - & - & 4.7 & - & 6.8 \\
$\mathbf{3}$ & 2.2 & - & - & 54.7 & - & - & 3.9 & 27.6 & 1 & - & - & - & - & 6.03 & 4.6 \\
$\mathbf{4}$ & 1.8 & - & - & 61.6 & - & - & 28.6 & - & 0.8 & 0.1 & 0.3 & - & - & - & 6.7 \\
$\mathbf{5}$ & 11.2 & - & - & 31.6 & - & - & 22.0 & - & 6.4 & 1 & - & - & - & - & 27.8 \\
$\mathbf{6}$ & 2.5 & - & 3.3 & 78.7 & - & - & 7.3 & - & 1.0 & - & - & - & - & - & 7.2 \\
$\mathbf{6}$ & 1.1 & - & 64.2 & 13.2 & - & - & 1.2 & - & 0.4 & - & - & - & - & 17.1 & 2.8 \\
$\mathbf{7}$ & 2.4 & - & - & 75.3 & - & - & 7.2 & - & 3.1 & 0.7 & - & - & - & - & 11.4 \\
$\mathbf{8}$ & 2 & - & - & 66.5 & - & 2.3 & 5.5 & - & 1.5 & - & - & - & - & - & 22.3 \\
$\mathbf{9}$ & 4.5 & - & - & 50.8 & 0.5 & 1.8 & 10.5 & - & 3.0 & 0.4 & 0.5 & - & - & - & 27.9 \\
$\mathbf{1 0}$ & 4.1 & - & - & 66.8 & - & 1.5 & 0.8 & - & 0.7 & 0.1 & 0.2 & - & - & 0.2 & 25.5 \\
$\mathbf{1 1}$ & 2.9 & - & - & 80.4 & 1.2 & - & 4.7 & - & 2 & 0.2 & - & - & - & - & 8.7 \\
$\mathbf{1 2}$ & 1.1 & - & - & 94.4 & - & - & - & - & 0.9 & - & - & - & - & - & 3.6 \\
\hline
\end{tabular}

The values shown for each element as percentages refer to the averages of three measurements. Indeed, the analyses of $\mathrm{X}$-ray fluorescence were carried out three times for each sample; more precisely, every percentage value comes from an average of three X-ray measurements, each realised on an about $2 \mathrm{~mm}^{2}$ area, performed by moving the probe into three different positions for each sample.

Except for samples 1 and 6, no punctual analyses were needed, as all the surfaces, with the exclusion of the two just mentioned and named $1_{p}$ and $6_{p}$ for clarity $(p=$ punctual), were quite homogeneous, as is reported in Figure 3.

All the sample surfaces are characterised by a high content of calcium, whose percentage stands quite often over the $50 \%$, and then by silicon, aluminium and potassium, ubiquitous as well. The high calcium content detected in most of the samples probably reflects intentional addition of a calcareous compound, possibly calcium carbonate, into the various paint layers.

It is worth stressing that iron was also quite widespread, although in this case, the outcome was due preponderantly to the presence onto the samples of pigments based on that element, as will be deeper explained in the next paragraphs.

The other elements that immediately leap out are undoubtedly mercury and sulphur (samples 1 and 3), lead (sample 2) and copper (samples 8, 9, 10), but it also worth noticing the presence of a large 
percentage of gold in sample $1 p$ and of barium and sulphur in sample $6 p$, keeping in mind that the latter are the outcomes of the punctual EDS analysis. The presence of barium was due to a tiny grain of $\mathrm{BaSO} 4$ that could be ascribed to modern building fragments in contact with the ancient ones in the same waste trench. It is worth noting that the presence of barium was highlighted only in one fragment.
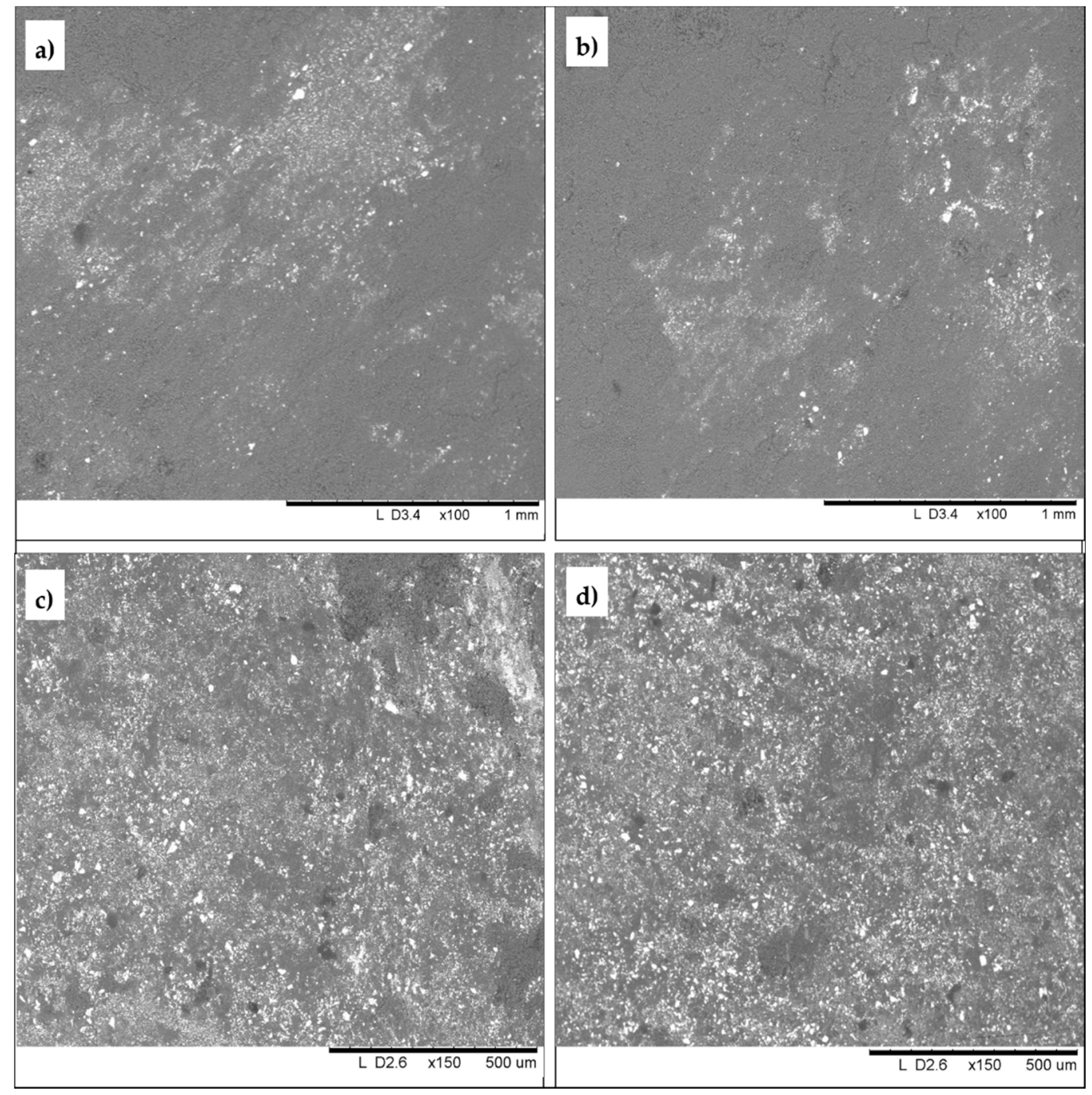

Figure 3. Representative SEM images showing that the fragments surfaces are generally homogeneous. (a,b) sample 1; (c,d) sample 3 .

These results allowed us to be fairly sure that samples 1 and 3 , which were red samples, were mainly composed of cinnabar (HgS), because of the contemporary presence of mercury and sulphur.

In all the other cases, the actual nature of the pigment on the surfaces could be only be hypothesised, since numerous might be the reasons to find iron, lead and copper in a painted layer. In fact, matching the information coming from the colour and the iron content, the presence of red ochre or hematite on the red samples 2 and 4 seemed quite probable, and of yellow ochre on sample 6; the same could not be stated for the light red/orange pigment, where the coexistence of such minerals could be hypothesised. An analogous argument can be proposed for the blue copper-based pigments 8,9 and 10; in fact, it is well known that a lot of green and blue shades in painting, especially in ancient artifacts, are due to copper compounds, and that is rather impossible to determine their actual nature by means of elemental analysis $[16,17]$.

As regards samples 7, since on the basis of its EDS spectrum the presence of copper and/or other elements that might be undeniably associated with green, blue and yellow pigments was excluded, 
it was supposed it could be green earth; on that note, it is worth recalling that sometimes a green hue can be obtained by mixing blue with yellow or also blue with pale green (such as green earth) pigments $[5,18]$.

As regards samples 11 and 12, the presence of almost nothing but calcium led us to suspect the presence of calcite in the white sample and to exclude the presence of iron or manganese-based pigments in the black one; as a consequence, the presence of a carbon-based pigment has been supposed, but of course without true evidence-only on the basis of elemental analysis.

It is evident that even though the outcomes of SEM-EDS analyses were quite significant, there were some residual doubts on the actual nature of almost all the pigments, so the samples underwent FTIR and Raman spectroscopic analyses. Depending on the sample, the Raman spectrum has been acquired with the bench tool (Thermo Fisher instrument), with the portable one (BW Tek instrument) or with both of them. Thus, in each figure, the excitation line is indicated.

The results inferred from the study of the vibrational spectra are synthetically reported for each sample in Table 3 and are discussed in detail in the following paragraphs, depending on the hues. It is worth noting that no band ascribable to the presence of organic materials was detected.

Table 3. SEM-EDS, ATR-FTIR and Raman results.

\begin{tabular}{|c|c|c|c|c|}
\hline Sample & Colour & $\begin{array}{l}\text { SEM-EDS Analysis } \\
\text { (Elements) }\end{array}$ & FTIR Peaks $\left(\mathrm{cm}^{-1}\right)$ & $\begin{array}{l}\text { Raman Peaks } \\
\left(\mathrm{cm}^{-1}\right)\end{array}$ \\
\hline 1 & bright red & $\begin{array}{c}\mathrm{Ca}, \mathrm{Hg}, \mathrm{Si}, \mathrm{Fe}, \mathrm{Al}, \mathrm{K}, \mathrm{S}, \\
\mathrm{Cl}, \mathrm{Au}\end{array}$ & $\begin{array}{c}1403,1032,1007,871,712 \\
532,472\end{array}$ & $253,284,343,1086$ \\
\hline 2 & red & $\mathrm{Ca}, \mathrm{Fe}, \mathrm{Si}, \mathrm{Pb}, \mathrm{Al}, \mathrm{K}$ & $\begin{array}{c}1409,1032,1009,913,872 \\
712,533,468\end{array}$ & $\begin{array}{r}147,223,253,291, \\
406,494,605,1086\end{array}$ \\
\hline 3 & bright red & $\mathrm{Ca}, \mathrm{Hg}, \mathrm{S}, \mathrm{Si}, \mathrm{Fe}, \mathrm{Al}, \mathrm{K}$ & $\begin{array}{c}1404,1024,872,712 \\
670,467\end{array}$ & $253,284,343,1086$ \\
\hline 4 & purple red & $\mathrm{Ca}, \mathrm{Fe}, \mathrm{Si}, \mathrm{Al}, \mathrm{K}, \mathrm{Na}, \mathrm{Mg}$ & $\begin{array}{c}1409,1090,872,794,712 \\
540,472\end{array}$ & $\begin{array}{l}223,288,404 \\
490,604\end{array}$ \\
\hline 5 & light red/orange & $\mathrm{Ca}, \mathrm{Si}, \mathrm{Fe}, \mathrm{Al}, \mathrm{K}, \mathrm{Mg}$ & $\begin{array}{c}1421,1032,1007,913,873 \\
797,779,712,693 \\
526,466\end{array}$ & $\begin{array}{c}143,284,405,463 \\
710,1086\end{array}$ \\
\hline 6 & yellow & $\mathrm{Ca}, \mathrm{Fe}, \mathrm{Si}, \mathrm{Ba}, \mathrm{Al}, \mathrm{K}, \mathrm{S}$ & $\begin{array}{c}1406,1032,1009,913,873 \\
797,712,532,468\end{array}$ & $284,391,712,1086$ \\
\hline 7 & green & $\mathrm{Ca}, \mathrm{Si}, \mathrm{Fe}, \mathrm{K}, \mathrm{Al}, \mathrm{Mg}$ & $\begin{array}{c}1414,970,873,798,712 \\
679,490,452\end{array}$ & - \\
\hline 8 & light blue & $\mathrm{Ca}, \mathrm{Si}, \mathrm{Fe}, \mathrm{Cu}, \mathrm{Al}, \mathrm{K}$ & $\begin{array}{l}1430,1160,1048,1008 \\
874,795,778,754,712 \\
663,593,519,472\end{array}$ & - \\
\hline 9 & light blue & $\begin{array}{c}\mathrm{Ca}, \mathrm{Si}, \mathrm{Fe}, \mathrm{Al}, \mathrm{K}, \mathrm{Cu}, \mathrm{Cl}, \\
\mathrm{Mg}, \mathrm{Na}\end{array}$ & $\begin{array}{c}1412,1160,1045,1008 \\
874,793,754,712,663 \\
593,519,467\end{array}$ & - \\
\hline 10 & light blue & $\begin{array}{c}\mathrm{Ca}, \mathrm{Si}, \mathrm{Al}, \mathrm{Cu}, \mathrm{Fe}, \mathrm{K}, \mathrm{Na} \text {, } \\
\mathrm{S}, \mathrm{Mg}\end{array}$ & 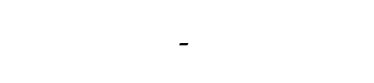 & - \\
\hline 11 & white & $\mathrm{Ca}, \mathrm{Si}, \mathrm{Fe}, \mathrm{Al}, \mathrm{K}, \mathrm{Cl}, \mathrm{Mg}$ & $1403,1033,872,712$ & $285,391,712,1086$ \\
\hline 12 & black & $\mathrm{Ca}, \mathrm{Si}, \mathrm{Al}, \mathrm{K}$ & $1403,1033,872,712$ & 1300,1580 \\
\hline
\end{tabular}

\subsection{Bright Red, Red, Purple Red, Light Red/Orange and Yellow}

Samples 1, 2, 3 and 4 showed various and evidently different red hues, even under simple naked-eye examination; in particular, the main chromatic dissimilarities were observed between the red and purple red colour groups, namely, samples 2, and 4, and the bright red couple of samples 1 and 3.

Sample 1 and sample 3 were characterised by a highly saturated bright red colour that was attributed mostly to the presence of cinnabar by SEM-EDS analys.es (see Table 2) [5], although iron was also found in both fragments. As regards sample 2, the elemental analysis suggested the contemporary 
presence of iron-based and lead-based pigments, whereas in sample 4 the SEM-EDS results led us to think that it was basically composed of iron oxide (see Table 2).

ATR-FTIR and Raman measurements were applied to confirm the presence of cinnabar in samples 1 and 3 and to investigate the possible presence of some red iron-based and/or lead-based pigments.

Figure 4 shows the ATR-FTIR spectra of red samples. All of them are characterised by the strong bands of calcium carbonate at 1403-1430, 871 and $712 \mathrm{~cm}^{-1}$ [19-22] and by a wide band around $1000 \mathrm{~cm}^{-1}$, due to the presence of silicate minerals [23,24], which is perfectly aligned with the elemental analysis results. In the following discussion, ubiquitous and well-known bands of calcite at 1403-1430, 871 and $712 \mathrm{~cm}^{-1}$ will be not taken into account.

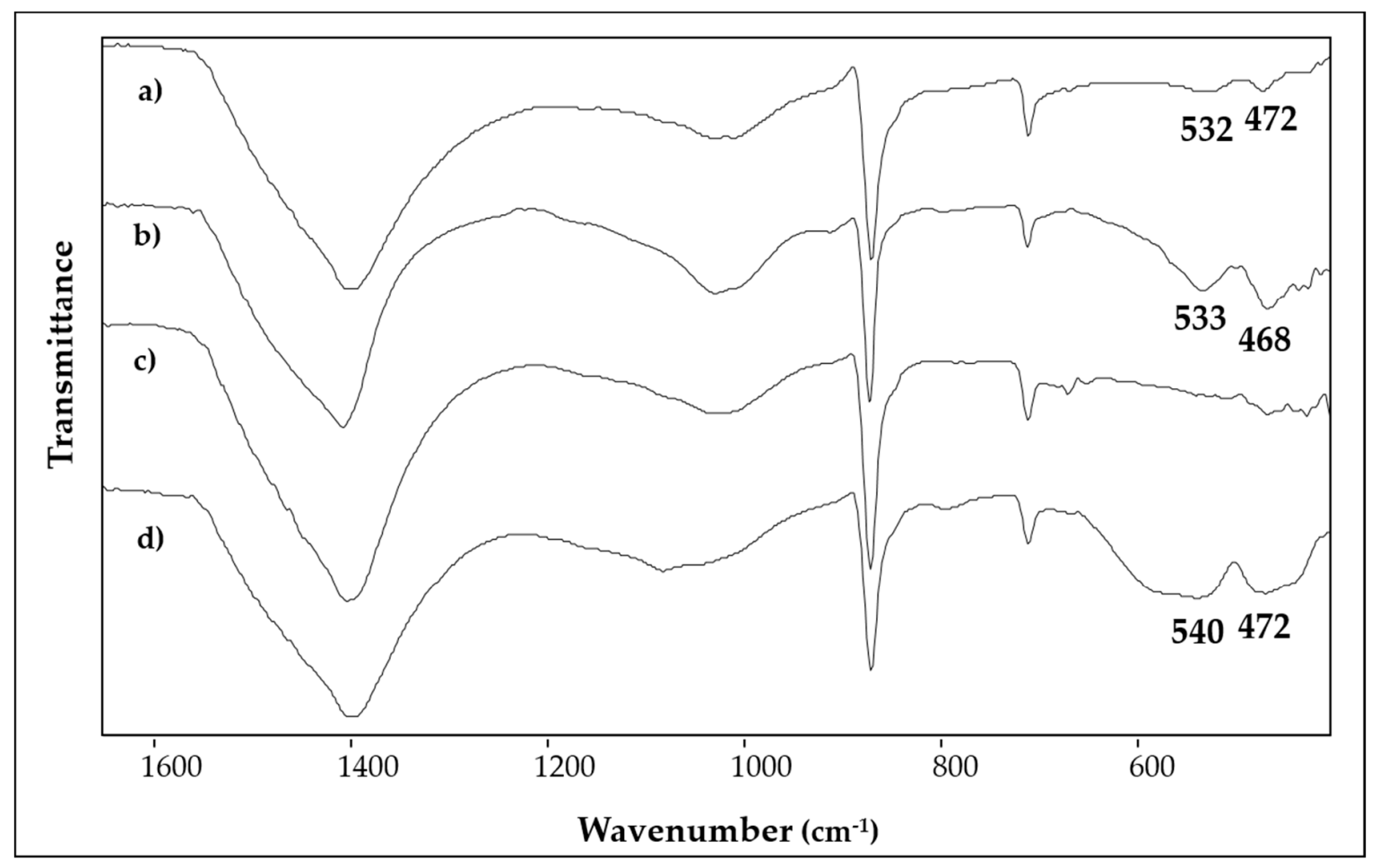

Figure 4. ATR-FTIR spectra of: (a) sample 1; (b) sample 2; (c) sample 3; (d) sample 4.

Actually, the most diagnostic zone of these spectra is the one from about 1200 to $450 \mathrm{~cm}^{-1}$, especially the wavenumber range below $700 \mathrm{~cm}^{-1}$, where the differences among the spectra are even more emphasised.

Sample 1, whose main bands stand at 1032, 1007, 532 and $472 \mathrm{~cm}^{-1}$ (Figure 4a), shows the features of a red ochre containing kaolinite [24-27]; in sample 3 the band at $1024 \mathrm{~cm}^{-1}$ (Figure 4c) suggests the presence of another silicate, possibly illite [28], whereas the bands of red ochre are barely detectable. This difference from the point of view of the composition could seemingly be due to a different provenance of the raw material, but this deserves further study.

The presence of cinnabar, hypothesised on the basis of the elemental analysis, was then confirmed by the results of Raman spectroscopy; the spectra of samples 1 (Figure 5e) and 3 (Figure 5d) have in fact its unmistakable features characterised by very strong bands at 253, 284 (sh) and $343 \mathrm{~cm}^{-1}$ [29]; the weak peak at $1086 \mathrm{~cm}^{-1}$ is due to calcite [30]. 


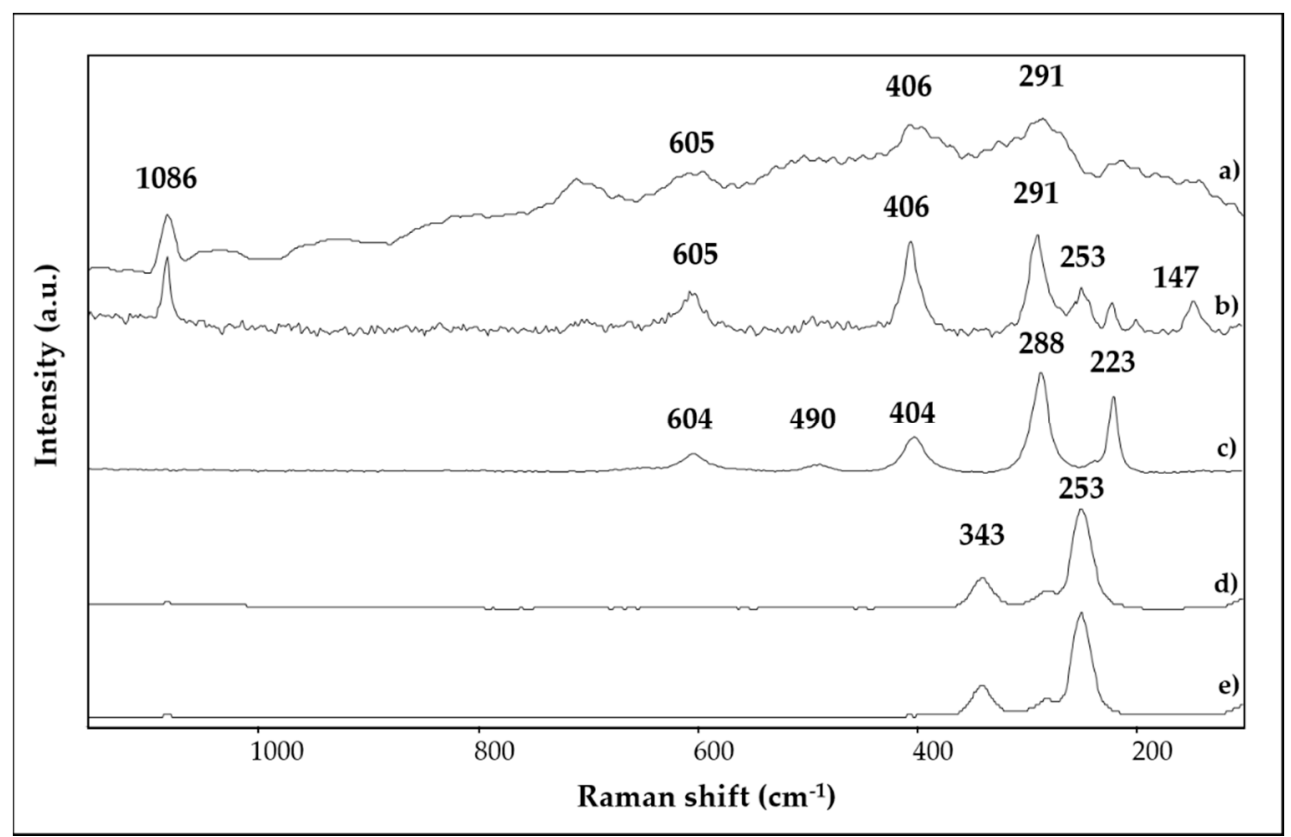

Figure 5. Raman spectra of (a) red sample $2\left(\lambda_{\mathrm{exc}}=1064 \mathrm{~nm}\right) ;(\mathbf{b})$ red sample $2\left(\lambda_{\mathrm{exc}}=785 \mathrm{~nm}\right)$; (c) purple red sample $4\left(\lambda_{\text {exc }}=785 \mathrm{~nm}\right)$; (d) bright red sample $3\left(\lambda_{\mathrm{exc}}=1064 \mathrm{~nm}\right) ;(\mathrm{e})$ bright red sample 1 $\left(\lambda_{\text {exc }}=1064 \mathrm{~nm}\right)$.

In sample 2 (Figure 4 b) the peaks at 1032, 1009, 913, 533 and $468 \mathrm{~cm}^{-1}$ are once again attributable to red ochre containing kaolinite [23-27,30-32].

Raman analysis confirmed the outcomes of FTIR analysis on the previously discussed samples; the spectra of red ochre characterised by peaks at 291, 406 and $605 \mathrm{~cm}^{-1}$ were obtained (Figure 5a,b) [33]. Additionally, in this case, the peak at $1086 \mathrm{~cm}^{-1}$ was due to calcite, whereas the band at $147 \mathrm{~cm}^{-1} \mathrm{can}$ be ascribed to lead oxide in its tetragonal form known as litharge [34]. The weak peak at $253 \mathrm{~cm}^{-1}$ could be associated with the presence of a low percentage of cinnabar, even though mercury does not appear in the EDS spectrum; we underline that the Raman spectrum in Figure $5 b$ was acquired by means of a punctual analysis performed by micro-Raman (whereas no spot analysis was performed with SEM-EDS on that sample), which implies that cinnabar was not uniformly distributed on the painting layer; moreover, the relative intensities of EDS peaks associated with $\mathrm{Hg}$ for samples 1 and 3, where cinnabar has been clearly detected, are quite low, so it seems plausible that the Hg signals were not detectable through SEM-EDS in sample 2. The small concentration of cinnabar in this sample shows that the painter apparently mixed different minerals to obtain the desired red hue. As already seen in samples 1 and 3, red ochre is frequently used as a layer beyond the final cinnabar coat but is rather unusual as a mixing element in a red ochre layer and is therefore a bit surprising.

The spectrum reported in Figure $4 \mathrm{~d}$ for sample 4 shows a trend that is rather more associable with $\mathrm{Fe}_{2} \mathrm{O}_{3}$ (haematite) than red ochre, because of the wavenumber and especially the shape of the bands at 540 and $472 \mathrm{~cm}^{-1}$ [26,27,32]; the broad bands at 1090 and $794 \mathrm{~cm}^{-1}$ are once again ascribable to silicate minerals, but not, as is typical in ochres, to kaolinite, giving strength to the hypothesis that pure haematite was present in this sample. It must be remarked that in this case Raman spectroscopy was very helpful, since the spectrum shown in Figure $5 \mathrm{c}$ is practically identical to the one of haematite, showing peaks at 223, 288, 404, 490 and $604 \mathrm{~cm}^{-1}$ [30]; that definitively made it possible to assign the nature of the purple red pigment in sample 4 .

ATR-FTIR spectra shown in Figure 6a,b refer respectively to light red/orange sample 5 and to yellow sample 6 . 


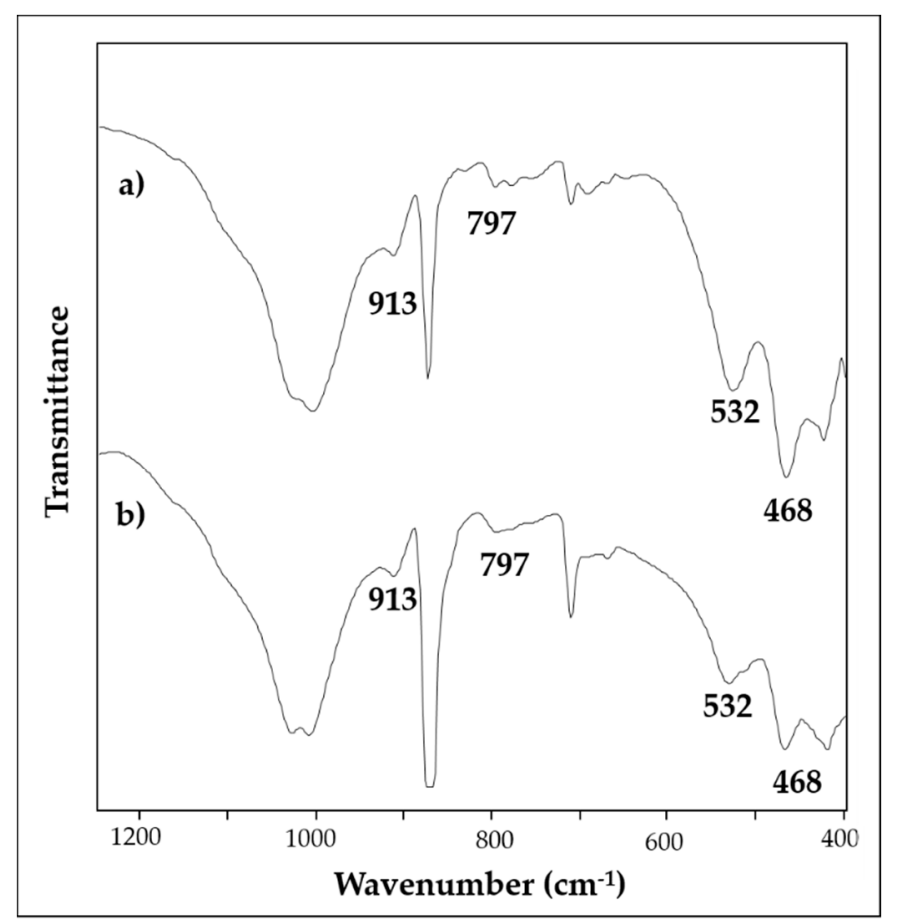

Figure 6. ATR-FTIR spectra of: (a) light red-/orange sample 5; (b) yellow sample 6.

Along with the strong bands at 873 and $712 \mathrm{~cm}^{-1}$ due to calcite and those at $1032,1009 \mathrm{~cm}^{-1}$ of silica [24,27], there are main peaks of yellow ochre at 913, 797, 532 and $468 \mathrm{~cm}^{-1}$ [26].

Raman analysis confirmed the presence of yellow ochre in sample 6 (Figure 7c), particularly because of the peak at $391 \mathrm{~cm}^{-1}$ attributed to goethite [33], whereas in sample 5 (Figure $7 \mathrm{~b}$ ) the peak at $405 \mathrm{~cm}^{-1}$ is attributable to red ochre [25], as in the already discussed sample 2 (included in Figure 7a for comparison). It must be noted that the micro-Raman analysis performed on sample 5 (Figure $7 \mathrm{~b}$ ), gave the strong band at $143 \mathrm{~cm}^{-1}$ of lead oxide, probably present in this case in its yellow orthorhombic form called massicot [35], and the peak at $463 \mathrm{~cm}^{-1}$ of quartz [26]. As in the case of sample 2, sample 5's micro-Raman spectroscopy revealed a composition that was slightly different from the one evinced by SEM-EDS measurements, as no lead was found; however, it must be stressed that no punctual SEM-EDS analyses were performed on sample 5, because none of the BSE images indicated the presence of any heavy metal on it. Since that sample had quite large dimensions, it seems probable that the measurements were not performed exactly on the same area by Raman and SEM-EDS techniques.

The ubiquitous peak at $710 \mathrm{~cm}^{-1}$ belongs to calcite, whose presence was even confirmed by the peak at $1086 \mathrm{~cm}^{-1}$ (not included in the figure).

Finally, the peak at $284 \mathrm{~cm}^{-1}$ achieved from each measurements presented in Figure 6, could be most likely assigned to calcite [30], but that is not to exclude that it might be the result of the superimposition of that band of calcite with the one in the $290-300 \mathrm{~cm}^{-1}$ range of red and yellow earth spectra $[25,26]$, so in this case, it was not that diagnostic.

Summing up the results of vibrational spectra analysis, it can be stated that there was yellow ochre on sample 6 . The light red/orange hue of sample 5 was instead probably intentionally obtained either as the overlapping of yellow and red painting or as a mixture of pigments with different yellow and red shades; more precisely, yellow ochre, red ochre and massicot were employed in this case [36].

Finally, on red, light red/orange and yellow samples, the feasibility of visible reflectance analysis was evaluated. In Figure 8a the reflectance spectra of samples 1 (bright red), 4 (purple red), 5 (light red/orange) and 6 (yellow) are shown. 


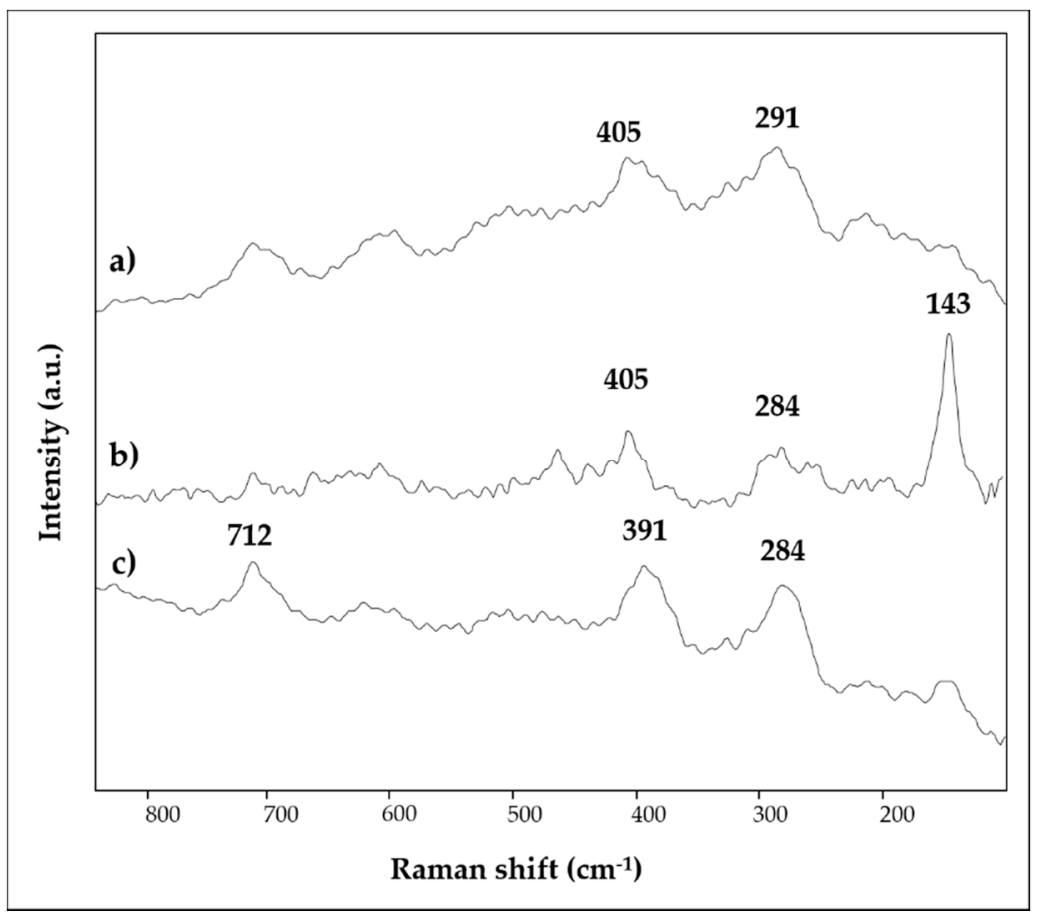

Figure 7. Raman spectra of (a) red sample $2\left(\lambda_{\mathrm{exc}}=1064 \mathrm{~nm}\right)$; (b) light red/orange sample 5 $\left(\lambda_{\text {exc }}=785 \mathrm{~nm}\right) ;(\mathrm{c})$ yellow sample $6\left(\lambda_{\mathrm{exc}}=1064 \mathrm{~nm}\right)$.

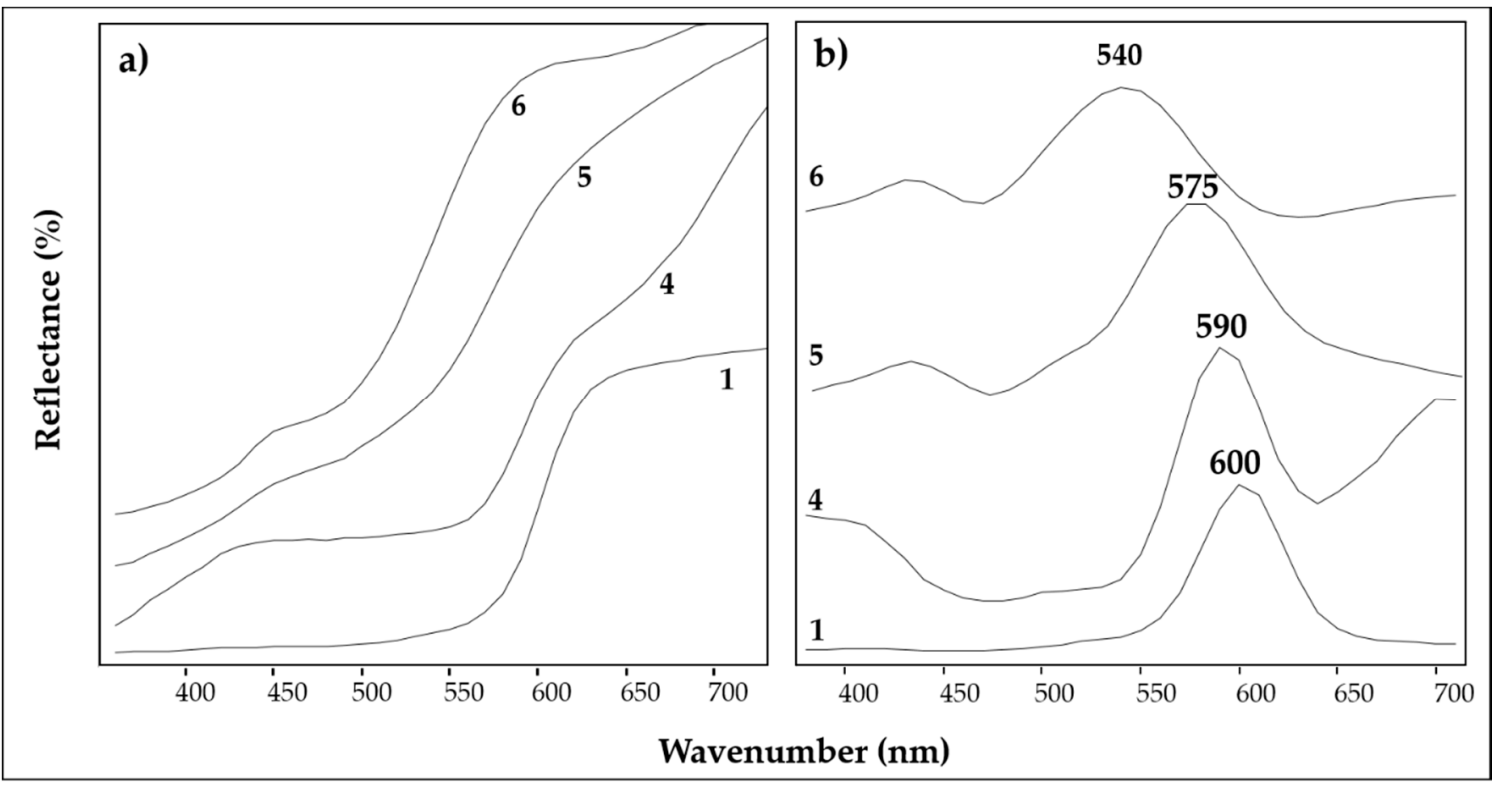

Figure 8. (a) Visible reflectance spectra of samples 1, 4, 5 and 6; (b) first derivatives of the spectra presented in (a).

The reflectance spectrum of sample 1 (the cinnabar-based sample) exhibited the typical semiconductor sigmoidal shape, characterised by a drastic rise around the inflexion point positioned in this case at $600 \mathrm{~nm}$ [37].

The features of red sample 4 (the haematite-based one) were instead mainly characterised by a positive slope at $590 \mathrm{~nm}$, whereas a second positive slope is evident at around $700 \mathrm{~nm}$. That shape matches what it is reported in the literature for red iron-based pigments [37-39].

As regards the yellow sample 6, it showed a profile that appeared very similar to that of the red sample, but in its case, the most pronounced slope stands at $540 \mathrm{~nm}$; two absorbance bands at about 
485 and $640 \mathrm{~nm}$ (readable as minima in the spectrum) were also detected. Once more the spectral trend resulting from the measurements here discussed conforms to the spectra of iron-based yellow pigments found in the literature [37-39].

Actually, the spectrum of sample 5 (that basically resulted in a red and yellow overlapped painting) showed a trend quite similar to that obtained from the iron-based pigments; however, in this case, the rapid slope is positioned almost between the red and the yellow samples, namely, at about $575 \mathrm{~nm}$; no trace of massicot was revealed by visible reflectance measurements on sample 5 .

The precise determination of the point of flex for each spectrum was performed by reading the maximum of the corresponding first derivative curve (Figure $8 \mathrm{~b}$ ).

All those observations are perfectly in accordance both with the literature [37-39] and with the previously discussed results concerning red and yellow pigments.

\subsection{Green}

ATR-FTIR spectrum of pale green sample 7, reported in Figure 9a, shows the characteristic bands at $970,798,679,490$ and $452 \mathrm{~cm}^{-1}$ ascribable to green earth and more likely to celadonite [23,29]; the bands at 1414,873 and $712 \mathrm{~cm}^{-1}$ are ascribable once more to calcite. This result matches perfectly with the previous SEM-EDS findings, since the detection of iron, silicon, potassium and aluminium is consistent with the composition of the green earth pigment [40].

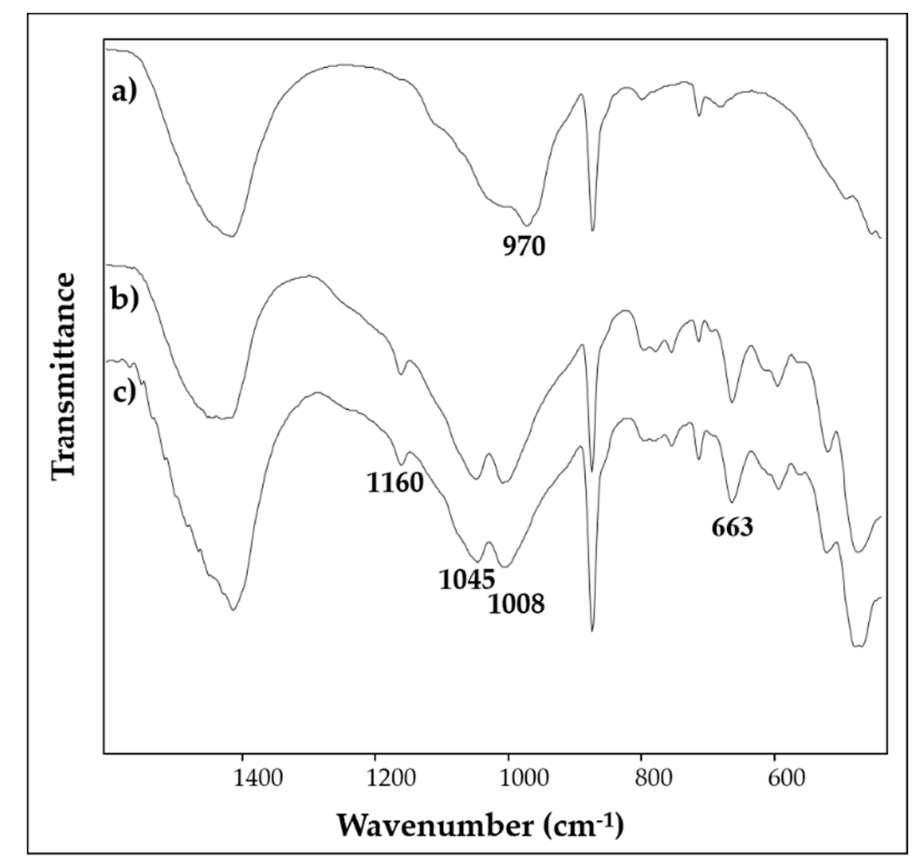

Figure 9. ATR-FTIR spectra of (a) sample 7, (b) sample 8, (c) sample 9.

\subsection{Light Blue}

ATR-FTIR spectra of blue samples 8 and 9 are reported in Figure $9 b, c$, and they both present the unequivocal features of Egyptian blue, it being characterised by peaks at 1160, 1048, 1008, 754, 663,593 and $519 \mathrm{~cm}^{-1}$ [4,41-43], whereas the band at about $470 \mathrm{~cm}^{-1}$ might belong to red ochre [35]. No decipherable Raman spectrum was obtained on blue samples, because of the presence of an extremely strong fluorescet background.

The SEM-EDS analyses clearly hint towards Egyptian blue for all the blue samples (see Table 2).

It is worth to note that from the chemical point of view the two stucco fragments show a composition similar to each other with given by the use of the pigment mixed with calcite. 


\subsection{White and Black}

Both ATR-FTIR spectra of white and black samples were just characterised by the bands of calcite at 1403,872 and $712 \mathrm{~cm}^{-1}$ and of silicate minerals at $1033 \mathrm{~cm}^{-1}$.

Those results allowed us to hypothesise that calcium carbonate, which is the main component of the substrate in all samples, might have also been used as a pigment in sample 11.

The Raman spectrum of sample 11 (Figure 10a) shows, above a huge fluorescence background, the peaks at 1086, 712 and $285 \mathrm{~cm}^{-1}$ associated with calcite [30], and a band at $391 \mathrm{~cm}^{-1}$ ascribable to goethite [33], whose presence may be due to some impurity of the white pigment or even to an intentional addition made to obtain that pale yellowish hue of sample 11.

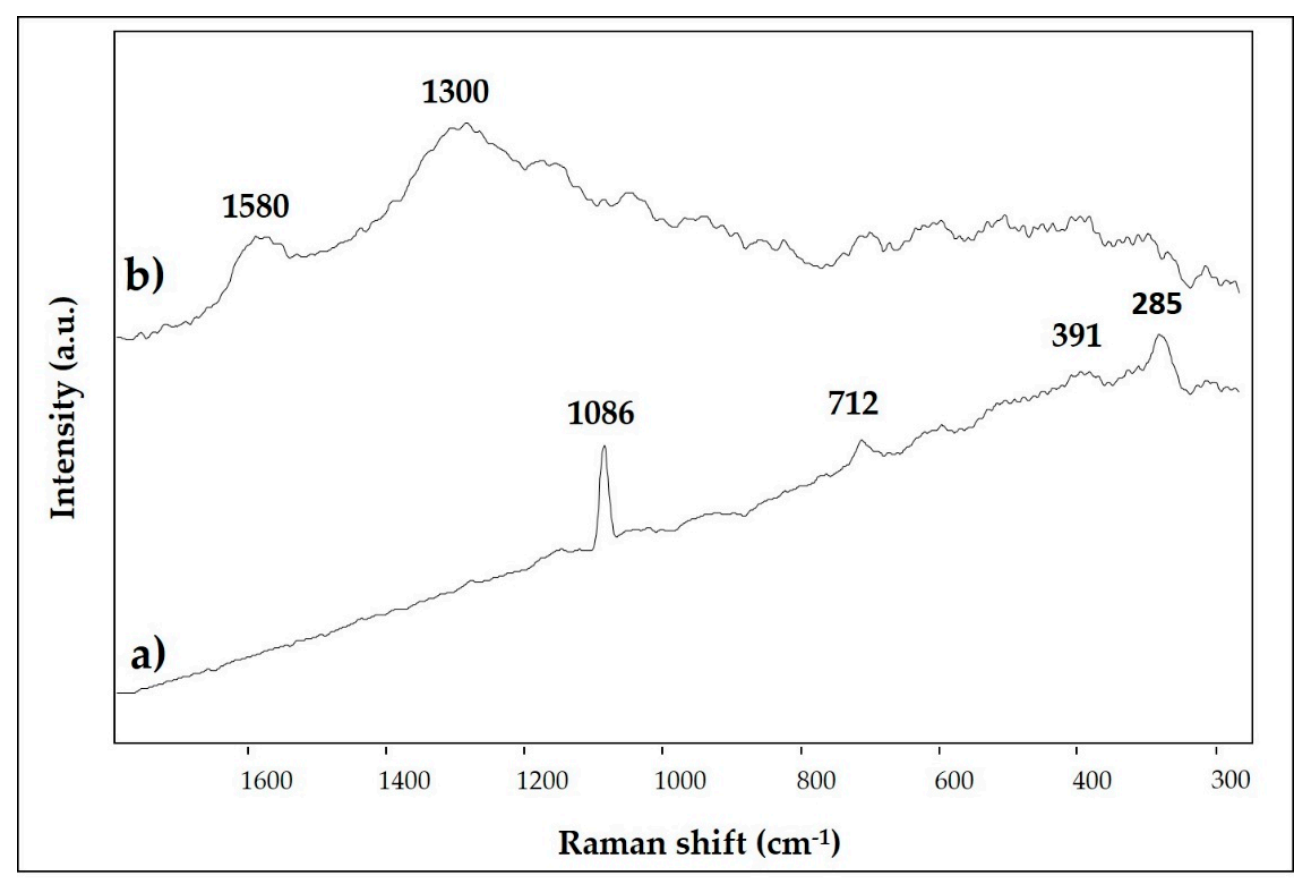

Figure 10. Raman spectra of (a) white sample $11\left(\lambda_{\text {exc }}=1064 \mathrm{~nm}\right) ;(\mathbf{b})$ black sample $12\left(\lambda_{\text {exc }}=1064 \mathrm{~nm}\right)$.

As regards the black pigment, nothing but calcite came from FTIR analysis and it was only possible to exclude the use of several compounds, as already stated in the SEM-EDS analysis paragraph.

By employing Raman spectroscopy, the black pigment was identified as carbon; in Figure 10b is the spectrum acquired from sample 12, which is characterised by the very broad bands at 1300 and $1580 \mathrm{~cm}^{-1}$ of black carbon [21,44].

\subsection{Golden Area on Sample 1}

The study of sample 1 was particularly interesting because it showed macroscopically small iridescent areas of gold colour. To confirm the hypothesis of the presence of gold on the pictorial surface, the study using SEM-EDS was fundamental. In fact, the morphological analysis has highlighted, on the surface, the presence of a painting layer, as shown in Figure 11.

The chemical investigation carried out punctually on this painting layer (Figure 11) showed the following composition: $\mathrm{Au}(95.4 \%)$ and $\mathrm{Ca}(4.7 \%)$. We also stress that if present, an organic binder could have been revealed and identified by employing GC-MS analysis; nevertheless, it was not possible to proceed in that way, because the necessary micro-sampling was not allowed on this sample.

This composition made it possible to assume the use of gold leaf on this pictorial surface, suggesting that the fragment could be part of some precious decoration probably commissioned by an illustrious and wealthy person, since the use of gold leaf as a decorative component on the pictorial surfaces of wall paintings is not so common in the surviving roman wall paintings. Among the most 
important and well-known examples at Rome are the decorated walls of the Aula Isiaca [45] and the Domus Aurea. The use of this technique is also evidenced by some fragments of Julio-Claudian painting fragments collected during the excavations of Vigna Barberini (Palatino, Rome) [46].

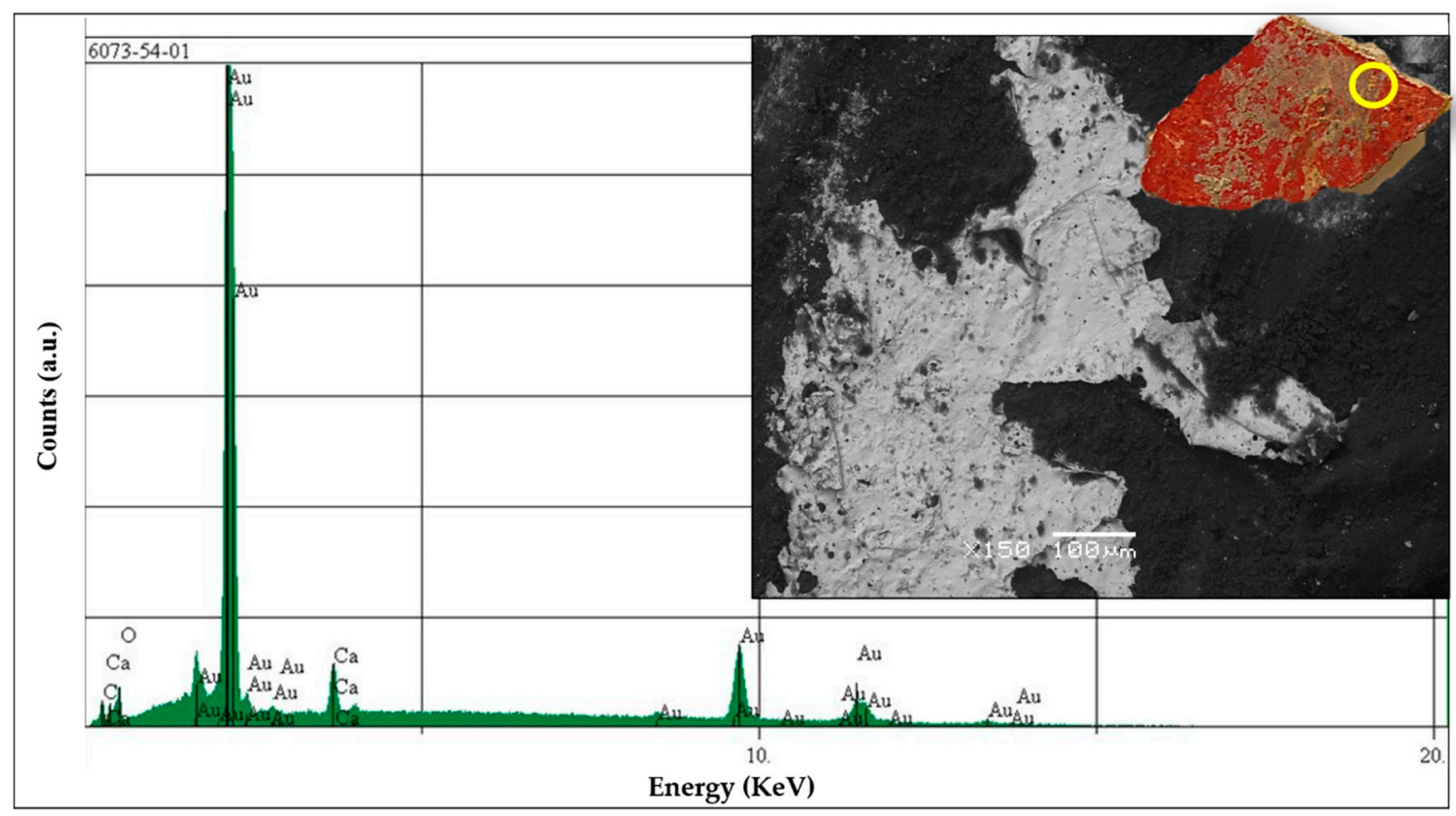

Figure 11. EDS spectrum acquired on sample 1 and the corresponding SEM image.

\section{Discussion}

Table 4 provides a summary of all the identified elements/compounds responsible for the colours for each analytical technique employed and for each sample, together with the proposed identification of the palette. The components belonging to the substrate, i.e., calcite and silicates, are not included.

Table 4. The main results obtained by means of the different instrumental techniques.

\begin{tabular}{|c|c|c|c|c|}
\hline Sample & SEM-EDS & ATR-FTIR & Raman & Pigments \\
\hline 1 & $\mathrm{Hg}+\mathrm{S}+\mathrm{Fe}+\mathrm{Au}$ & red ochre & cinnabar & $\begin{array}{c}\text { cinnabar + gold leaf } \\
+ \text { red ochre }\end{array}$ \\
\hline 2 & $\mathrm{Fe}+\mathrm{Pb}$ & red ochre & $\begin{array}{c}\text { red ochre + litharge } \\
+ \text { cinnabar }\end{array}$ & $\begin{array}{l}\text { red ochre + litharge } \\
+ \text { cinnabar }\end{array}$ \\
\hline 3 & $\mathrm{Hg}+\mathrm{S}+\mathrm{Fe}$ & red ochre & cinnabar & cinnabar + red ochre \\
\hline 4 & $\mathrm{Fe}$ & haematite & haematite & haematite \\
\hline 5 & $\mathrm{Fe}$ & red + yellow ochre & red ochre + massicot & $\begin{array}{c}\text { red ochre }+ \text { massicot } \\
+ \text { yellow ochre }\end{array}$ \\
\hline 6 & $\mathrm{Fe}$ & yellow ochre & yellow ochre & yellow ochre \\
\hline 7 & $\mathrm{Fe}$ & celadonite & - & green earth \\
\hline 8 & $\mathrm{Cu}$ & Egyptian blue & - & Egyptian blue \\
\hline 9 & $\mathrm{Cu}$ & Egyptian blue & - & Egyptian blue \\
\hline 10 & $\mathrm{Cu}$ & - & - & Egyptian blue \\
\hline 11 & $\mathrm{Ca}$ & calcite & calcite + yellow ochre & calcite + yellow ochre \\
\hline 12 & - & - & amorphous carbon & carbon black \\
\hline
\end{tabular}

On the basis of the results obtained, it can be stated that the palette employed for the decorations involved the use of numerous pigments and sometimes a simultaneous application of them, indicating a certain level of skill of the artists. In particular, the presence of pigments such as cinnabar, far more precious than red ochre, and the use of gold leaf, could indicate an important commission. 
Former analyses of cinnabar fresco fragments have already demonstrated that this pigment was often applied upon an aragonite or yellow ochre coat [47], and on a red ochre layer [48], as detected in this study.

The absence of organic binders is another important feature of the samples that strongly hints towards the employment of the fresco technique [49]. The fact that calcite is mixed with all the identified pigments is further evidence of fresco technique employment.

Thanks to the synergic use of both a portable Raman spectrophotometer and a conventional instrument, a bench tool, it was possible to characterise the entire colour palette.

The use of the portable facility might also allow us, in the future, to perform chemical analysis in a non-destructive way, i.e., without the necessity of withdrawing some samples.

This study showed that Raman spectroscopy is an extremely effective technique in pigment identification. The two instruments clearly have different characteristics and performances. In particular, we underline that the spatial resolution obtainable with a portable instrument equipped with a fibre optic probe is not equivalent to that of a micro-Raman spectrometer. In fact, the use of the microscope makes it possible both to observe in detail and to focus the laser source on single grains, as observed, for example, in the case of sample 2. However, the portable instrument has the great advantage of being able to carry out the analyses in a completely non-destructive manner, and therefore to be potentially usable in situ, i.e., directly on painted surfaces.

From this point of view, another important tool that could be successfully applied thanks to its great versatility and the low cost of the instrumentation, is represented by the colourimetric investigation.

The measurements presented in this study have concerned only red and yellow samples and only the visible reflectance results were investigated, but since the technique seems promising, the investigation might be extended to other fragments; it must be also said that this technique can hardly be as effective as FTIR and Raman spectroscopies in identifying mixtures.

It is worth noticing that in cases of pigmented surfaces, in particular, for large ones, both portable Raman spectroscopy and colourimetric analysis can be employed to carry out a preliminary survey useful for identifying where an in-depth study with destructive techniques could be useful.

\section{Conclusions}

A multi-analytical approach was applied to study some pigmented fragments from Roman wall paintings. In particular, the combined use of the different techniques allowed disclosing the entire palette employed by the artists, including not only single pigments (such as cinnabar, red and yellow ochre, Egyptian blue and green earth) but also mixtures of them.

Some interesting aspects, which could only be hypothesised archeologically, have now been successfully confirmed, for example, the presence of gold leaf decoration for a few painting fragments we had (sample 1; another example on a cinnabar layer is actually preserved at Rome). Regarding the pigments, as well, some worth-mentioning features can be highlighted. First of all, the presence of a red ochre layer beyond the analysed cinnabar wall painting fragments (samples 1 and 3). As we well know from ancient literature and from surviving Roman wall paintings, cinnabar was an expensive pigment imported to Rome and distinguished by a high risk of chemical transformation (blackening).

It is also interesting that in red sample 2, a different red pigment, derived from lead, was observed. This particular mix of pigments was probably made on purpose to adjust the hue of the painting layer and might be related to diachronic painting fragments and/or their pertinence to different Roman buildings.

The presence of some unusual chemical elements, for example, barium, is probably related to the nature of the archaeological discovery. As mentioned above, the ancient shards were collected in a modern waste trench, which could have caused contamination with modern building rests.

Finally, the white sample 10, on which yellow ochre traces were noticed, probably has to be considered a fragment with yellow overpainted motifs, as verified on better conserved shards belonging to the same assemblage. 
Furthermore, from the point of view of the analytical approach applied, it has been highlighted that the portable instrumentation (Raman spectroscopy and reflectance spectroscopy investigations) is suitable for the identification of pigments without invoking more expensive tools. The employment of portable devices might provide a rapid and effective overview directly on vast wall paintings, giving the opportunity to one to perform either totally non-destructive analysis (without any sampling from the artwork itself) or at least to target the sampling in order to do it as few times as possible.

Author Contributions: Conceptualisation, P.F. and M.A.; methodology, V.C. and V.G.; formal analysis, V.C.; C.A.L., V.G. and F.D.; investigation, V.C., C.A.L. and V.G.; data curation, V.C. and V.G.; writing-original draft preparation, P.F., V.G. and V.C.; writing-review and editing, P.F., M.A., F.D.; supervision, P.F. and M.A. All authors have read and agreed to the published version of the manuscript.

Funding: This research received no external funding.

Acknowledgments: We would like to acknowledge Daniel Barchewitz (B\&W Tek), Andrea Cipolla (Metrohm Italiana) and Valerio Pasini (Thermo Fisher) for their scientific support and for having provided us with the Raman instrumentation. Special thanks for the permission to publish these first results go to Sergio Mineo, archaeologist of the Parco Archeologico dell'Appia Antica and editor of the forthcoming volume "Antichità di Monte d'Oro," which will contain the archaeological study of the discovery. We also are grateful Italo Campostrini for his help for some SEM-EDS measurements.

Conflicts of Interest: The authors declare no conflict of interest.

\section{References}

1. Siddall, R. Mineral pigments in archaeology: Their analysis and the range of available materials. Minerals 2018, 8, 201. [CrossRef]

2. Bonizzoni, L.; Bruni, S.; Gargano, M.; Guglielmi, V.; Zaffino, C.; Pezzotta, A.; Pilato, A.; Auricchio, T.; Delvaux, L.; Ludwig, N. Use of integrated non-invasive analyses for pigment characterisation and indirect dating of old restorations on one Egyptian coffin of the XXI dynasty. Microchem. J. 2018, 138, $122-131$. [CrossRef]

3. Fermo, P.; Delnevo, E. Analisi e caratterizzazione dei pigmenti dei dipinti murali dei secoli I-IV d.C. In Caelius II. Pars Inferior. Le Case Romane sotto la Basilica dei Ss. Giovanni e Paolo; Englen, A., Filetici, M.G., Palazzo, P., Pavolini, C., Santolini, R., Eds.; L’Erma di Bretschneider: Roma, Italy, 2015; pp. 466, 468, 471, 473, 479.

4. Fermo, P.; Piazzalunga, A.; De Vos, M.; Andreoli, M. A multi-analytical approach for the study of the pigments used in the wall paintings from a building complex on the Caelian Hill (Rome). Appl. Phys. A Mater. 2013, 113, 1109-1119. [CrossRef]

5. Aliatis, I.; Bersani, D.; Campani, E.; Casoli, A.; Lottici, P.P.; Mantovan, S.; Marino, I.G.; Ospitali, F. Green pigments of the Pompeian artists' palette. Spectrochim. Acta A 2009, 73, 532-538. [CrossRef] [PubMed]

6. Fermo, P.; Mearini, A.; Bonomi, R.; Arrighetti, E.; Comite, V. Integrated analytical approach for the characterisation of repainted wooden statues dated to the fifteenth century. Microchem. J. 2020, 157, 105072. [CrossRef]

7. Ruffolo, S.A.; La Russa, M.F.; Barca, D.; Casoli, A.; Comite, V.; Nava, G.; Crisci, G.M.; De Francesco, A.M.; Miriello, D. Mineralogical, petrographic and chemical analyses for the study of the canvas "Cristo alla Colonna" from Cosenza, Italy: A case study. Period. Mineral. 2010, 79, 71-79. [CrossRef]

8. La Russa, M.F.; Belfiore, C.M.; Comite, V.; Barca, D.; Bonazza, A.; Ruffolo, S.A.; Crisci, G.M.; Pezzino, A. A scientific approach to the characterisation of the painting technique of an author: The case of Raffaele Rinaldi. Appl. Phys. A 2014, 114, 733-740. [CrossRef]

9. La Russa, M.F.; Ricca, M.; Cerioni, A.; Chilosi, M.G.; Comite, V.; De Santis, M.; Rovella, N.; Ruffolo, S.A. The colours of the Fontana di Trevi: An analytical approach. Int. J. Archit. Herit. 2018, 12, 114-124. [CrossRef]

10. Comite, V.; Ricca, M. Diagnostic investigation for the study of the fresco "Madonna con il bambino", from Cosenza, southern Italy: A case study. Rend. Online Soc. Geol. Ital. 2016, 38, 21-24. [CrossRef]

11. Crupi, V.; Fazio, B.; Fiocco, G.; Galli, G.; La Russa, M.F.; Licchelli, M.; Majolino, D.; Malagodi, M.; Ricca, M.; Ruffolo, S.A.; et al. Multi-analytical study of Roman frescoes from Villa dei Quintili (Rome, Italy). J. Archaeol. Sci. Rep. 2018, 21, 422-432. [CrossRef] 
12. Miriello, D.; Bloise, A.; Crisci, G.M.; De Luca, R.; De Nigris, B.; Martellone, A.; Osanna, M.; Pace, R.; Pecci, A.; Ruggieri, N. Non-destructive multi-analytical approach to study the pigments of wall painting fragments reused in mortars from the archaeological site of pompeii (Italy). Minerals 2018, 8, 134. [CrossRef]

13. Alberghina, M.F.; Macchia, A.; Capizzi, P.; Schiavone, S.; Ruffolo, S.A.; Comite, V.; Barberio, M.; La Russa, M.F. Surface and volume non-invasive methods for the structural monitoring of the bass-relief "Madonna con Bambino" (Gorizia, Northern Italy). Nat. Prod. Res. 2019, 33, 1034-1039. [CrossRef]

14. Tarquini, O.; Pronti, L.; Lorenzetti, E.G.; Felici, A.C. Pigment identification on campana reliefs from the palatine hill and colosseum valley in Rome. J. Cult. Herit. 2020, 43, 294-302. [CrossRef]

15. Cappelletti, G.; Ardizzone, S.; Fermo, P.; Gilardoni, S. The influence of iron content on the promotion of the zircon structure and the optical properties of pink coral pigments. J. Eur. Ceram. Soc. 2015, 25, 911-917. [CrossRef]

16. Bonizzoni, L.; Bruni, S.; Galli, A.; Gargano, M.; Guglielmi, V.; Ludwig, N.; Lodi, L.; Martini, M. Non-invasive in situ analytical techniques working in synergy: The application on graduals held in the Certosa di Pavia. Microchem. J. 2016, 126, 172-180. [CrossRef]

17. Bonizzoni, L.; Bruni, S.; Guglielmi, V.; Milazzo, M.; Neri, O. Field and laboratory multi-technique analysis of pigments and organic painting media from an Egyptian coffin (26th dynasty). Archaeometry 2011, 53, 1212-1230. [CrossRef]

18. Mazzocchin, G.A.; Agnoli, F.; Mazzocchin, S.; Colpo, I. Analysis of pigments from Roman wall paintings found in Vicenza. Talanta 2003, 61, 565-572. [CrossRef]

19. Tintori, L. Conservazione, Tecnica e Restauro Degli Affreschi; Mitteilungen des Kunsthistorischen Institutes: Florenz, Italy, 1975; pp. 149-180.

20. Andersen, F.A.; Brecevic, L. Infrared spectra of amorphous and crystalline calcium carbonate. Acta Chem. Scand. 1991, 45, 1018-1024. [CrossRef]

21. Bruni, S.; Guglielmi, V.; Della Foglia, E.; Castoldi, M.; Bagnasco Gianni, G. A non-destructive spectroscopic study of the decoration of archaeological pottery: From matt-painted bichrome ceramic sherds (southern Italy, VIII-VII B.C.) to an intact Etruscan cinerary urn. Spectrochim. Acta A Mol. Biomol. Spectrosc. 2018, 191, 88-97. [CrossRef]

22. Gulotta, D.; Bertoldi, M.; Bortolotto, S.; Fermo, P.; Piazzalunga, A.; Toniolo, L. The Angera stone: A challenging conservation issue in the polluted environment of Milan (Italy). Environ. Earth Sci. 2013, 69, 1085-1094. [CrossRef]

23. Chukanov, N.V. Infrared Spectra of Mineral Species, 3rd ed.; Springer: Berlino, Germany, 2014; pp. $14-1726$.

24. Saikia, B.J.; Parthasarathy, G. Fourier transform infrared spectroscopic characterizazion of kaolinite from Assam and Meghalaya, Northeastern India. J. Mod. Phys. 2010, 1, 206. [CrossRef]

25. di Lernia, S.; Bruni, S.; Cislaghi, I.; Cremaschi, M.; Gallinaro, M.; Gugliemi, V.; Mercuri, A.M.; Poggi, G.; Zerboni, A. Colour in context. Pigments and other coloured residues from the Early-Middle Holocene site of Takarkori (SW Libya). Archaeol. Anthropol. Sci. 2015, 8, 381-402. [CrossRef]

26. Bikiaris, D.; Daniilia, S.; Sotiropoulou, S.; Katsimbiri, O.; Pavlidou, E.; Moutsatsou, A.P.; Chryssoulakis, Y. Ochre-differentiation through micro-Raman and micro-FTIR spectroscopies: Application on wall paintings at Meteora and Mount Athos, Greece. Spectrochim. Acta A Mol. Biomol. Spectrosc. 2000, 56, 3-18. [CrossRef]

27. Helwig, K. The Characterization of Iron Earth Pigments Using IR Spectroscopy, in Postprints of IRUG2; Pretzel, B., Ed.; Victoria \& Albert Museum (V\&A): London, UK, 1998; pp. 83-91.

28. Zviagina, B.B.; Drits, V.A.; Dorzhieva, O.V. Distinguishing Features and Identification Criteria for K-Dioctahedral 1M Micas (Illite-Aluminoceladonite and Illite-Glauconite-Celadonite Series) from Middle-Infrared Spectroscopy Data. Minerals 2020, 10, 153. [CrossRef]

29. Aliatis, I.; Bersani, D.; Campani, E.; Casoli, A.; Lottici, P.P.; Mantovana, S.; Marino, I.G. Pigments used in Roman wall paintingsin the Vesuvian area. J. Raman Spectrosc. 2010, 41, 1537-1542. [CrossRef]

30. Burgio, L.; Clark, R.J.H. Library of FT-Raman spectra of pigments, minerals, pigment media and varnishes, and supplement to existing library of Raman spectra of pigments with visible excitation. Spectrochim. Acta A 2001, 57, 1491-1521. [CrossRef]

31. Genestar, C.; Pons, C. Earth pigments in painting: Characterisation and differentiation by means of FT-IR spectroscopy and SEM-EDS microanalysis. Anal. Bioanal. Chem. 2005, 382, 269-274. [CrossRef] 
32. Mortimore, J.L.; Marshall, L.J.R.; Almond, M.J.; Hollins, P.; Matthews, W. Analysis of red and yellow ochre samples from Clearwell Caves and Catalhoyuk by vibrational spectroscopy and other techniques. Spectrochim. Acta A Mol. Biomol. Spectrosc. 2004, 60, 1179-1188. [CrossRef]

33. Froment, F.; Tournié, A.; Colomban, P. Raman identification of natural red to yellow pigments: Ochre and iron-containing ores. J. Raman Spectrosc. 2008, 39, 560-568. [CrossRef]

34. Burgio, L.; Clark, R.J.H.; Firth, S. Raman spectroscopy as a means for the identification of plattnerite $(\mathrm{PbO} 2)$, of lead pigments and of their degradation products. R. Soc. Chem. 2001, 126, 222-227. [CrossRef]

35. Smith, G.D.; Clark, R.J.H. discience. J. Archaeol. Sci. 2004, 31, 1137-1160. [CrossRef]

36. Carmen Edreira, M.; José Feliu, M.; Fernández-Lorenzo, C.; Martín, J. Spectroscopic study of Egyptian blue mixed with other pigments. Helv. Chim. Acta 2003, 86, 29-49. [CrossRef]

37. Aceto, M.; Agostino, A.; Fenoglio, G.; Idone, A.; Gulmini, M.; Picollo, M.; Ricciardi, P.; Delaneyf, J.K. Characterisation of colourants on illuminated manuscripts by portable fibre optic UV-visible-NIR reflectance spectrophotometry. Anal. Methods 2014, 6, 1488-1500. [CrossRef]

38. Elias, M.; Chartier, C.; Prevot, G.; Garay, H.; Vignaud, C. The colour of ochres explained by their composition. Mater. Sci. Eng. B 2006, 127, 70-80. [CrossRef]

39. Cheilakou, E.; Troullinos, M.; Koui, M. Identification of pigments on Byzantine wall paintings from Crete (14th century AD) using non-invasive Fiber Optics Diffuse Reflectance Spectroscopy (FORS). J. Archaeol. Sci. 2014, 41, 541-555. [CrossRef]

40. Zagora, J. SEM-EDX Pigment Analysis and Multi-Analytical Study of the Ground and Paint layers of Francesco Fedrigazzi's Painting from Kostanje. CeROArt EGG 2013. Available online: http://journals. openedition.org/ceroart/3248(3) (accessed on 30 July 2020).

41. Ormanci, O. Non-destructive characterisation of Egyptian Blue cakes and wall painting fragments from the east of Lake Van, Turkey. Spectrochim. Acta A Mol. Biomol. Spectrosc. 2020, 229, 117889. [CrossRef]

42. Vahur, S.; Teearu, A.; Peets, P.; Joosu, L.; Leito, I. ATR-FT-IR spectral collection of conservation materials in the extended region of 4000-80 $\mathrm{cm}^{-1}$. Anal. Bioanal. Chem. 2016, 408, 3373-3379. [CrossRef]

43. Database of ATR-FT-IR Spectra of Various Materials. Available online: http://lisa.chem.ut.ee/IR_spectra/ paint/pigments/egyptian-blue/ (accessed on 31 July 2020).

44. Tomasini, E.P.; Halac, E.B.; Reinoso, M.; Di Liscia, E.J.; Maier, M.S. Micro-Raman spectroscopy of carbon-based black pigments. J. Raman Spectrosc. 2012, 43, 1671-1675. [CrossRef]

45. Bandinelli, R.B. Roma. L'arte Romana nel Centro del Potere; BUR: Milano, Italy, 2015; p. 123.

46. Maurina, B. Intonaci di età Tardorepubblicana e Augustea Provenienti Dagli Scavi di Vigna Barberini (Palatino, Roma): Una panoramica, Mélanges de l'École française de Rome-Antiquité. Available online: https://journals.openedition.org/mefra/4737 (accessed on 28 July 2020).

47. Bearat, H. Quelle est la gamme exacte des pigments romains? Confrontation des résultats d'analyse avec les textes de Vitruve et de Pline. In Roman Wall Paintings. Materials, Techniques, Analysis and Conservation; Bearat, H., Fuchs, M., Maggetti, M., Paunier, D., Eds.; Institute of Mineralogy and Petrography: Fribourg, Switzerland, 1997; pp. 11-34.

48. Barbet, A.; Allag, C. La pittura romana. In Dal Pittore al Restauratore; Ciurletti, G., Scagliarini, C.D., Eds.; Bononia University Press: Bologna, Italy, 2000; p. 44.

49. Cortea, I.M.; Ghervase, L.; Tentea, O.; Constantina, A. Pârău \& Roxana Rădvan first analytical study on second-century wall paintings from ulpia traiana sarmizegetusa: Insights on the materials and painting technique. Int. J. Archit. Herit. 2020, 14, 751-761.

(C) 2020 by the authors. Licensee MDPI, Basel, Switzerland. This article is an open access article distributed under the terms and conditions of the Creative Commons Attribution (CC BY) license (http://creativecommons.org/licenses/by/4.0/). 